\title{
T lymphocytes of the normal human cornea
}

\author{
O F SCHEIFFARTH, F H STEFANI, N GABRIEL, AND O-E LUND
}

From the University Eye Hospital, Munich, Federal Republic of Germany

SUMMARY Lymphocytes in the periphery of the normal human cornea are identified as being only $\mathrm{T}$ lymphocytes by immunhistochemical methods. OKT-4 positive cells ( $\mathrm{T}$-helper/inducer lymphocytes) and OKT-8 positive cells (T-suppressor/cytotoxic lymphocytes) are found in similar numbers in most of the corneas examined. OKT-4 positive cells in the cornea present a risk of transferring HTLV-III (HIV) by corneal grafting.

Lymphocytes are present in the epithelium and the stroma of the normal human cornea even in the absence of any pathological process.' They occur sporadically in the periphery and in low numbers in more central parts of the cornea.

Lymphocytes can be specified into their subtypes by means of monoclonal antibodies against different epitopes of glycoprotein nature on the cells. Meanwhile an increasing number of different clones and antibodies is produced reacting with the same subtype of leucocytes. Recently the Committee on Human Leucocyte Differentiation Antigens proposed a new nomenclature system using the so-called cluster designation (CD) to characterise the cells and their antigens. ${ }^{2}$ For instance, T-helper/inducer cells are characterised by the cluster CD4, corresponding to a variety of antibodies like T4, Leu3a, or 91D6. The cytotoxic/suppressor subset of $T$ lymphocytes in this nomenclature is characterised by the cluster designation $\mathrm{CD} 8$ corresponding to a number of monoclonal antibodies like Leu2a, TB, M236, etc. ${ }^{2}$ Some of these antibodies are produced commercially, such as OKT-4 (T-helper/inducer cells), OKT-8 (suppressor/cytotoxic T cells), and OKT-3, OKT-11 (all T cells, T cells forming E-rosettes.) ${ }^{34}$ Even B lymphocytes can be identified by an antibody like OKB-7. ${ }^{56}$

These antibodies became an important tool for analysing immune mechanisms under normal and pathological conditions. One of the most recent instances is the aquired immune deficiency syndrome (AIDS), a disease caused by the human T-lymphotropic virus type III (HTLV-III, HIV), which injures the T-helper/inducer cells and finally leads to opportunistic infections and neoplasms. Meanwhile

Correspondence to Dr Otto F Scheiffarth, University Eye Hospital, Mathildenstr. 8, D-8000 München 2, Federal Republic of Germany. it seems to be proved that the CD4 antigen is an essential and specific component of the receptor for the HTLV-III. ${ }^{7-10}$

\section{Material and methods}

We examined 20 normal corneas which had been obtained as fresh donor material for keratoplasty. A specimen of the corneal periphery was excised and cryostat sections cut at $-20^{\circ} \mathrm{C}$. The sections were allowed to dry at room temperature and were fixed in acetone for 10 minutes.

Histochemical staining of lymphocytes was performed by immunoperoxidase technique: (1) pretreatment of tissue with normal serum; (2) incubation with the primary mouse monoclonal antibody; (3) incubation with antimouse immunoglobulin (linking reagent); (4) incubation with peroxidase labelled mouse IgG; (5) addition of the substrate reagent (amino-ethylcarbazole and hydrogenperoxide). After each step the specimens were washed several times with phosphate buffered saline.

As primary antibody we used the OKB-7 antibody as reagent for B lymphocytes and OKT-11 for T cells in general. T-helper/inducer cells were identified by the OKT-4 antibody and the T-suppressor/cytotoxic subset by the OKT-8 antibody.

\section{Results}

Specimens of the periphery of 20 different corneas were examined, and lymphocytes were identified by immunohistochemical staining in 16 samples. Using the OKB-7 antibody we could detect no B lymphocytes in the cornea. Positive controls for the binding of B lymphocytes to the OKB-7 antibody were performed with fresh tissue obtained from tonsil- 


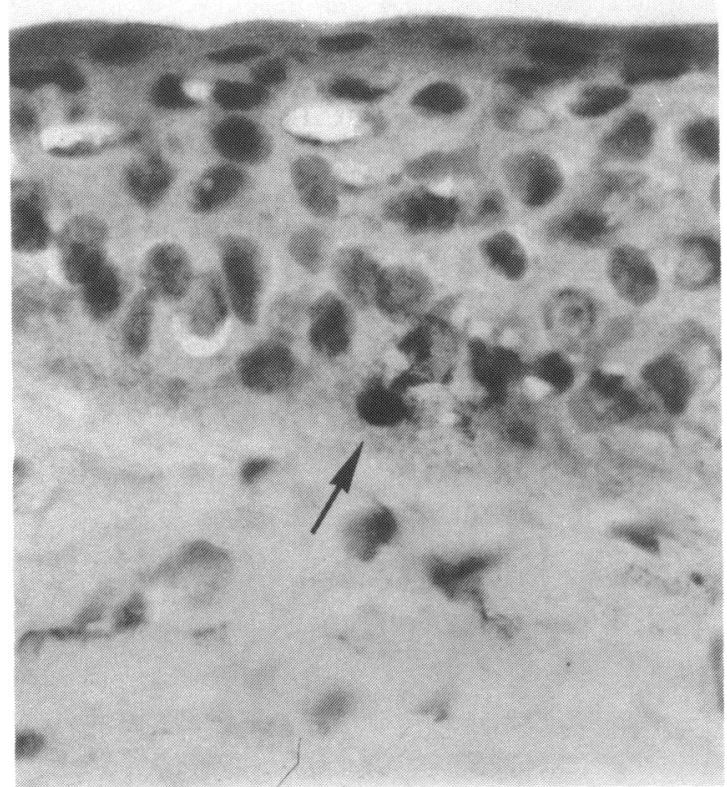

Fig. 1 Immunoperoxidase staining of a T4 lymphocyte in a normal human cornea.

lectomy. The sections were processed in the same way as described for the corneal specimens. All lymphocytes were identified as T cells (Fig. 1). False positive results due to artefacts could be excluded by using murine ascites fluid instead of the primary antibody in the immunoperoxidase technique. In most cases (10 specimens) T4-positive and T8-positive cells could be classified in about similar numbers, while in two samples more T4-positive cells and in four samples more T8-positive cells were found. But for quantitative analysis of the exact ratio of T4/T8 cells in these circumstances, namely a sporadic distribution in the cornea, a large number of sections from different parts of the cornea is necessary, which we did not obtain.

\section{Discussion}

Lymphocytes are present as $\mathrm{T}$ cells in the normal human cornea even in absence of any inflammatory process. While they are quite common in the periphery of the cornea, they also occur sporadically in the central part of the cornea. In most corneas T4positive and T8-positive cells occur in similar numbers. An exact quantitative determination needs large numbers of sections from different parts of the cornea, which were not obtained in this study.

These $\mathrm{T}$ lymphocytes probably migrate into the cornea from the limbal vessels. Their exact function in the defence mechanism of the cornea is unknown.

The finding of T4-positive cells in the normal human cornea is of great interest in connection with the possible transfer of the aquired immune deficiency syndrome (AIDS) by a keratoplasty. Since the CD4 (T4) antigen is an essential component of the receptor for the AIDS retrovirus, ${ }^{7-11}$ the question arises whether lymphocytes occurring in normal corneas could possibly transmit HTLV-III in corneal grafting, though no transmission of HTLV-III by corneal grafting has yet been reported. HTLV-III has been demonstrated in tears of patients suffering from AIDS." This has led to proposals from the Centers for Disease Control. ${ }^{12}$ No advice for corneal grafting was recommended at that time, possibly because no documented case of AIDS transmission by corneal grafting has yet occurred.

The Eye Bank Association of America uses two screening techniques to detect infected donor corneas: (1) identification of high-risk individuals, and (2) seropositivity detected by the enzyme linked immunosorbent assay (ELISA) test. ${ }^{13}$ Pepose et al. ${ }^{14}$ have discussed the safety of these screening methods. Meanwhile HTLV-III has also been demonstrated in corneal epithelial cells of a donor with a positive serum antibody to HTLV-III. ${ }^{15}$ The virus was not demonstrated in keratocytes or endothelium of the cornea. Along with these findings corneal grafting bears a so far unknown potential risk of transplanting the infection. We also wish to stress O'Day's point: $:^{13}$ 'the risk-benefit ratio needs to be considered carefully'.

\section{References}

1 Hogan MJ, Zimmerman LE. Ophthalmic pathology. 2nd ed. Philadelphia, London: Saunders, 1962: 278.

2 Committee of Human Leucoycte Differentiation Antigens. IUIS-WHO Nomenclature Subcommittee. Immunology Today 1984; 5: 158-9.

3 Reinherz EL, Schlossman SF. Regulation of the immune response-inducer and suppressor T-lymphocyte subsets in human beings. $N$ Engl J Med 1980; 303: 370-3.

4 Reinherz EL, Schlossman SF. The differentiation and function of the human T lymphocytes. Cell 1980; 19: 821-7.

5 Mittler RS, Talle MA, Carpenter K, Rao PE, Goldstein G. Generation and characterisation of monoclonal antibodics reactive with human B-lymphocytes. J Immunol 1983; 131: 1754-162.

6 Knowles DM, Tolidjian B, Marboc CC, Mittler RS, Talle MA, Goldstein G. Distribution of antigens defined by OKB monoclonal antibodies on benign and malignant lymphoid cclls and on nonlymphoid tissues. Blood 1984; 63: 886-96.

7 Dalgleish AG, Beverly PCL, Clapham PR, Crawford DH, Greaves MF, Weiss RA. The CD4(T4) antigen is an essential component of the receptor for the AIDS retrovirus. Nature 1984; 312: $763-7$.

8 Klatzmann D, Champagne E, Chamaret S, et al. T-lymphocyte T4 molecule behaves as the receptor for human retrovirus LAV. Nature 1984; 312: 767-8. 
9 McDougal JS, Mawle A, Cort SP, et al. Cellular tropism of the human retrovirus HTLV-III/LAV. I. Role of T-cell activation and expression of the T4 antigen. J Immunol 1985; 135: $3151-62$.

10 McDougal JS, Kennedy MS, Sligh JM, Cort SP, Mawle A, Nicholson JKA. Binding of HTLV-III/LAV to T4 + T-cells by a complex of the $110 \mathrm{~K}$ viral protein and the T4 molecule. Science 1986; 231: 382-5.

11 Fujikawa LS. Salahuddin SZ, Lane HC, et al. On the presence of HTLV-III in the tears of patients with AIDS. 20th Annual Meeting, Ocular Microbiology and Immunology Group, San Francisco, 28 Sept 1985.

12 Centers for Disease Control. Recommendations for preventing possible transmission of human T-lymphotropic virus type III/ lymphadenopathy-associated virus from tears. Morbidity and Mortality Weekly Report 1985; 34: 533-4.

13 O'Day DM. Editorial: The risk posed by HTLV-III-infected corneal donor tissuc. Am J Ophthalmol 1986; 101: 246-7.

14 Pepose JS, Mac Rac S, Guinn TC, Holland GN. Editorial: The impact of the AIDS epidemic on corncal transplantation. $A m \mathrm{~J}$ Ophthalmol 1985; 100: 610-3.

15 Salahuddin SZ, Palestine AG, Heck E, et al. Isolation of human T-cell leukemia/lymphotropic virus type III from the cornea. $A m$ J Ophthalmol 1986; 101: 149-52.

Accepted for publication $8 \mathrm{July} 1986$. 